УДК 343.412

DOI https://doi.org/10.32849/2663-5313/2020.4.55

Оксана Степаненко,

канд. юрид. наук,

дочент кафедри кримінального права

Національного університету «Одесъка юридична академія»

Каріна Агапова,

магістр права

\title{
КІЛЬКІСНИЙ КРИТЕРІЙ СИСТЕМАТИЧНОСТІ ЯК ОЗНАКА ДОМАШНЬОГО НАСИЛЬСТВА
}

У статті розкрито зміст систематичності як ознаки домашнього насильства. Встановлено, що систематичність характеризується двома критеріями: кількісним (тобто багаторазовістю періодично здійснюваних дій) та якісним (тобто взаємозв'язком, внутрішньою єдністю, шо утворюють певну лінію поведінки винного щодо конкретного потерпілого чи потерпілих). Лише за наявністю як кількісного, так $і$ якісного критерію можна стверджувати, що насильство має систематичний характер. Зміст кількісного критерію систематичності як ознаки домашнього насильства передбачає вчинення особою три і більше разів діяння (ия сукупність охоплює також попереднє притягнення до адміністративної відповідальності). Зроблено висновок, що систематичним учиненням фізичного, психологічного або економічного насильства (далі - насильства) в контексті ст. 126 -1 Кримінального кодексу України (далі - КК Украӥни) слід розуміти такі випадки: особа вчиняє насильство три і більше разів, за кожне з яких не була притягнута до відповідальності; особа вчиняє насильство, за яке не була притягнута до відповідальності й раніше була притягнута два і більше разів до адміністративної відповідальності за ст. 173-2 Кодексу України про адміністративні правопорушення (далі - КУпАП) «Вчинення домашнього насильства, насильства за ознакою статі, невиконання термінового заборонного припису або неповідомлення про місце свого тимчасового перебування» (далі - cm. 173-2 КУпАП); особа вчиняє насильство два рази, за кожне з яких не була притягнута до відповідальності, але була притягнута один раз до адміністративної відповідальності за ст. 173-2 КУпАП. Таких комбінацій може бути дуже багато, проте, коли має місие преюдиційність, важливо встановити новий епізод вчинення насильства після попереднього притягнення до адміністративної відповідальності. На основі аналізу практики Європейського суду з прав людини (далі - ЄСПЛ) установлено, що, коли особа вчинила декілька разів домашнє насильство й за кожне таке діяння була притягнута до адміністративної відповідальності за ст. 173-2 КУпАП, то притягнення ї̈ за ті ж самі діяння за ознакою систематичності до кримінальної відповідальності за ст. 126-1 КК Украӥни є порушенням приниипу «поп bis in idem» у розумінні ст. 4 Протоколу № 7 до Конвенцї про захист прав людини.

Ключові слова: домашнє насильство, систематичність, систематичність домашнього насильства, non bis in idem.

Постановка проблеми. Відповідно до Закону України «Про внесення змін до Кримінального та Кримінального процесуального кодексів України з метою реалізації положень Конвенції Ради Свропи про запобігання насильству стосовно жінок і домашньому насильству та боротьбу з цими явищами» від 6 грудня 2017 р., який набрав чинності 11 січня 2019 р., у КК України з'явилася нова стаття 126-1 «Домашне насильство».

Відповідно до вказаної статті домашне насильство - це умисне систематичне вчинення фізичного, психологічного або економічного насильства щодо подружжя чи колишнього подружжя або іншої особи, 3 якою винний перебуває (перебував) у сімейних або близьких відносинах, що призводить до фізичних або психологічних страждань, розладів здоров'я, втрати працездатності, емоційної залежності або погіршення якості життя потерпілої особи.

Метою статті є спроба розкрити поняття
«систематичності» як обов'язкової ознаки
насильства в указаному складі злочину.
Адже, враховуючи, що така ознака є оці-
нювальною, на практиці можуть виникати
труднощі щодо її встановлення й опису
в процесуальних документах.

Виклад основного матеріалу. У чинному КК України ознака систематичності є у положеннях як Загальної, так і Особливої частин. 
У ч. 2 ст. 78 , ч. 5 ст. 79 , ч. 5 ст. 83 КК України систематичність згадується в контексті систематичного вчинення правопорушень, що спричинили адміністративні стягнення й свідчать про небажання стати на шлях виправлення. Відповідно до усталеної практики систематичним учиненням правопорушень вважається вчинення засудженим трьох і більше правопорушень, за які його було притягнуто до адміністративної відповідальності.

В положеннях Особливої частини КК України систематичність як ознака об'єктивної сторони складу злочину перед-

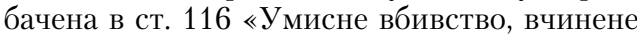
в стані сильного душевного хвилювання» (систематичне знущання); ст. 120 «Доведення до самогубства» (систематичне приниження людської гідності або вчинення систематичного протиправного примусу до дій, що суперечать волі); ст. 150-1 «Використання малолітньої дитини для заняття жебрацтвом» (систематичного випрошування грошей, речей, інших матеріальних цінностей у сторонніх осіб); ст. $390 \ll$ Ухилення від відбування покарання у виді обмеження волі та у виді позбавлення волі» (систематичне порушення громадського порядку чи встановлених правил проживання). Відповідно до Постанови Пленуму Верховного Суду України «Про судову практику у справах про злочини проти життя та здоров'я» систематичним приниженням людської гідності $€$ тривале принизливе ставлення до потерпілого (постійні образи, глум над ним тощо).

Аналіз коментарів до вказаних статей КК України, наукової літератури й судової практики дає можливість зазначити, що систематичність характеризується двома критеріями: кількісним, тобто багаторазовість періодично здійснюваних дій, і якісним, тобто взаємозв'язком, внутрішньою єдністю, що утворюють певну лінію поведінки винного щодо конкретного потерпілого чи потерпілих. Лише за наявністю як кількісного, так і якісного критерію можна стверджувати, що насильство має систематичний характер. В межах дослідження сконцентруємо свою увагу саме на кількісному критерії систематичності.

Кількісна ознака вказує на кількість діянь, що становлять об'єктивну сторону злочину. M.I. Бажанов свого часу вказував, що систематичність означає вчинення діяння більше ніж два рази (тобто три й більше), якщо протиправні дії є вираженням певної негативної тенденції в поведінці винуватої особи [1, с. 56]. О. Дудоров і М. Хавронюк, даючи тлумачення систематичності, відзначають, що вона «означає постійну повторюваність тотожних чи схожих дій (чи бездіяльності), кожна з яких сама по собі може створювати враження незначної, але в сукупності вони впливають на потерпілу особу надзвичайно негативно, i інтенсивність цього впливу може залежати як від ступеня агресивності кожного окремого діяння, так і від їхньої кількості». Учені додають, що закінченим злочин вважається з моменту вчинення хоча $б$ однієї з трьох форм насильства (фізичного, психологічного чи економічного) втрете, в результаті чого настав хоча б один з указаних в законі наслідків. Не має значення, чи було відображено в адміністративному протоколі поліції, у терміновому заборонному приписі, в обмежувальному приписі чи в іншому документі факт перших двох актів насильства. Звісно, для доказування факт документування має значення, але не більше, ніж інші передбачені законом докази - показання потерпілих, свідків, висновки експертиз тощо [2, с. 78]. Таким чином, учені визначають мінімальну кількість діянь особи: мінімум три

Тобто кількісний критерій систематичності як ознака домашнього насильства полягає в учиненні особою трьох і більше актів насильства (фізичного, психологічного чи економічного).

Що стосується судової практики з указаного питання, варто зазначити, що більшою мірою суди також установлюють як мінімум три епізоди прояву насильства, для того щоб установити систематичність домашнього насильства. Так, вироком Буського районного суду Львівської області від 1 березня 2019 р. встановлено, що чоловік (ОСОБА 1) 12 січня 2019 р. вчинив відносно своєї дружини (ОСОБА 2) дії психологічного насильства. Пізніше, 21 січня 2019 р. ОСОБА 1вчиниввідносноОСОБА 2діїфізичного та психологічного насильства. 22 січня 2019 р. ОСОБА 1 вчинив відносно ОСОБА 2 дії психологічного насильства. Ввечері цього ж дня, приблизно о 22:00, ОСОБА 1 вчинив відносно ОСОБА 2 дії психологічного та фізичного насильства. Підсумовуючи, суд робить висновок, що вказаними насильницькими діями ОСОБА 1 заподіяв дружині (ОСОБА_2) систематичні фізичні та психологічні страждання, що завдали шкоди фізичному та психічному здоров'ю потерпілої [3]. В аналізованому судовому рішенні суд розкриває 4 епізоди, щоб кваліфікувати дії винного за ст. 126-1 КК України.

Ще одним прикладом є Вирок Мукачівського Міськрайонного суду Закарпатської області від 28 березня 2019 р., в якому суд розкриває 3 епізоди насильства. Зокрема, 10 лютого 2019 р. ОСОБА 1 вчинив відносно своєї рідної сестри (ОСОБА_2) дії 
психологічного насильства. Також 10 лютого 2019 p. ОСОБА_1 вчинив відносно ОСОБА_2 дії фізичного та психологічного насильства. Крім цього, 18 лютого 2019 р. ОСОБА_1 вчинив відносно ОСОБА_2 дії психологічного насильства. Вказаними насильницькими діями ОСОБА 1 заподіяв рідній сестрі ОСОБА_2 систематичних фізичних і психологічних страждань, що завдали шкоди iiï фізичному та психічному здоров’ю [4].

Тобто суди встановлюють щонайменше три епізоди вчинення фізичного, психологічного або економічного насильства, за жодний з яких особа не притягувалась до відповідальності. Разом із тим є низка судових рішень, де систематичність складають випадки притягнення особи до адміністративної відповідальності. Так, у вироку Лугинського районного суду Житомирської області від 3 травня 2019 р. вказано, що ОСОБА_2, яку тричі притягували до адміністративної відповідальності за ч. 2 ст. 173-2 КУпАП, 24 січня 2019 р., близько 19:00 вчинив психологічне насильство над своєю дружиною (ОСОБА 3). Внаслідок таких систематичних дій ОССБА_2 потерпілій (ОСОБА_3) завдано емоційного пригнічення та погіршення психологічного самопочуття, а також сімейних відносин [5]

Таким чином, для встановлення систематичності як ознаки злочину, передбаченого статтею 126-1 КК України, судом взято до уваги те, що особа три рази притягувалась до адміністративної відповідальності за ст. 173-2 КУпАП, а наступний факт вчинення насильства, в цьому випадку психологічного, стало підставою для притягнення особи до кримінальної відповідальності.

У судовій практиці є ще один достатньо цікавий підхід щодо врахування попереднього притягнення особи до адміністративної відповідальностізаст. 173-2. Так, у рішенні Овруцького районного суду Житомирської області від 8 травня 2019 р. зазначено, що ОСОБА_1 11 лютого 2019 р. в присутності своєї неповнолітньої доньки (ОСОБА 3) вчинив відносно своєї колишньої дружини (ОСОБА_2) дії фізичного та психологічного насильства, внаслідок чого було викликано працівників поліції, які по приїзду припинили протиправні дії ОСОБА_1 та склали проти нього протокол про вчинення адміністративного правопорушення, передбаченого ч. 2 ст. 173-2 КУпАП. Далі в рішенні описані ще три епізоди вчинення схожих дій, за які щодо ОСОБА_1 було складено протокол про вчинення адміністративних правопорушень, передбачених ч. 2 ст. 173-2 КУпАП. За всі вищезазначені дії постановою Овруцького районного суду Житомирській області від 20 березня 2019 р. ОСОБА_1 визнано винним і притягнуто до адміністративної відповідальності. П Підсумовуючи зазначене, суд робить висновок, що таким чином ОСОБА_1 вчинив умисне систематичне домашнє насильство щодо своєї колишньої дружини ОСОБА_2, що призвело до фізичних та психологічних страждань останньої, а також погіршило якість їі життя. Суд ухвалив ОСОБА_1 визнати винним у скоєнні кримінального правопорушення, передбаченого ст. 126-1 КК України [6].

Аналізуючи таку судову практику, Ватутінський міський суд Черкаської області у свої роз'ясненнях зазначає: «...якщо особу кілька разів (не менше трьох) притягнуто до адміністративної відповідальності за вчинення насильства в сім'ї за ст. 173-2 КУпАП, указане є підставою для порушення кримінального провадження стосовно цієї особи» [7].

Ми своєю чергою вважаємо, що в аналізованому випадку відбувається не що інше як притягнення особи двічі до відповідальності за одне і те саме діяння. Адже в кожному випадку за вчинення домашнього насильства особа понесла адміністративну відповідальність, а потім за сукупність таких дій кримінальну. Враховуючи сказане, доцільно встановити, як така судова практика співвідноситься 3 принципом «non bis in idem» (заборони притягнення до відповідальності або покарання двічі за одне й те саме діяння).

Право не бути притягненим до суду або покараним двічі за одне й те саме діяння закріплено в ст. 4 Протоколу № 7 до Конвенції про захист прав людини і основоположних свобод (далі - Конвенція): «1. Нікого не може бути вдруге притягнено до суду або покарано в порядку кримінального провадження під юрисдикцією однієї й тієї самої держави за правопорушення, за яке його вже було остаточно виправдано або засуджено відповідно до закону та кримінальної процедури цієї держави. 2. Положення попереднього пункту не перешкоджають відновленню провадження у справі згідно 3 законом та кримінальною процедурою відповідної держави за наявності нових або нововиявлених фактів чи в разі виявлення суттєвих недоліків у попередньому судовому розгляді, які могли вплинути на результати розгляду справи. 3. Жодних відступів від положень цієї статті не допускається на підставі ст. 15 Конвенції» [8]. Це право також закріплено у ст. 61 Конституції України, в якій зазначається, що ніхто не може бути двічі притягнений до юридичної відповідальності одного виду за одне й те саме правопорушення. 
Важливо розглянути практику ЄСПЛ щодо вказаного питання, а саме рішення у справі «Oliveira проти Швейцарії». Пані Олівейру спочатку визнали винною в адміністративному правопорушенні, згодом у кримінальному. Цюрихський окружний суд у рішенні зазначає, що принцип «non bis in idem» притягнення до адміністративної відповідальності виключає можливість подальшого кримінального переслідування особи, проте оскільки ретельне розслідування показало, що ті самі факти становлять більш серйозне, кримінально каране порушення, то перше рішення й покарання повинні бути скасовані. Розмір штрафу в другому процесі був зменшений з урахуванням уже сплаченої суми стягнення на підставі першого рішення. Суд за цією справою дійшов висновку, що це типовий приклад, коли одне діяння становить два окремих правопорушення. У таких випадках, на думку Суду, як правило, більше покарання поглинає менше [9].

О.М. Дроздов, аналізуючи вищевказане рішення ЄСПЛ та інші рішення, які так чи інакше стосуються принципу «non bis in idem», робить висновок, що принцип «non bis in idem» застосовується, як правило, у кримінальному провадженні та провадженні щодо адміністративних правопорушень. Водночас, визначаючи сферу дії ст. 4 Протоколу № 7 , слід керуватися трьома критеріями, широко відомими як «критерії Енгеля», які повинні враховуватися під час визначення того, було чи не було у справі висунуте «кримінальне обвинувачення». Першим критерієм є правова кваліфікація правопорушення відповідно до національного права, другим - сам характер правопорушення, а третім - ступінь суворості покарання, яке може бути застосоване до винної особи. Оцінку відповідним обставинам справи ЄСПЛ надає за розробленим ним алгоритмом: а) чи було перше провадження кримінальним за своїм характером; b) чи були правопорушення, за які переслідувався заявник, одними й тими самими (idem); с) чи було дублювання проваджень (bis). Очевидно, що Суд відносить до кримінально-правових також окремі види адміністративних правопорушень. ЄСПЛ вважає, що вислів «одне й те саме правопорушення» за ст. 4 Протоколу № 7 треба сприймати в тому сенсі, що вона забороняє переслідувати чи судити одну особу за друге правопорушення, якщо останне походить із тих самих фактів або фактів, що «по суті» є такими ж, як і ті, по яких мало місце перше правопорушення. Ця гарантія набирає чинності, коли розпочато нове переслідування, а попереднє рішення про виправдання чи засудження вже набуло законної сили.
Водночас перше рішення повинно бути «остаточним» за своєю суттю, а далі вже слід з'ясувати, чи було воно «кримінальним» у значенні ст. 4 (1) Протоколу № 7, витлумачене у світлі загальних принципів розуміння понять «кримінальне обвинувачення» у ст. 6 і «покарання» у ст. 7 Європейської Конвенції про захист прав людини і основоположних свобод (далі - СКПЛ) [10].

Враховуючи зазначене, вважаємо, що якщо особа вчинила декілька разів домашне насильство й за кожне таке діяння була притягнута до адміністративної відповідальності, то притягнення за ці ж самі діяння за ознакою систематичності є ні чим іншим як порушенням принципу «non bis in idem» в розумінні ст. 4 Протоколу № 7 до СКПЛ.

Підсумовуючи вищезазначене, вважа$€ м 0$, що систематичним учинення фізичного, психологічного або економічного насильства в контексті ст. 126-1 КК України, слід розуміти такі випадки:

1) особа вчиняє насильство три і більше разів, за кожне з яких не була притягнута до відповідальності;

2) особа вчиняє насильство, за яке не була притягнута до відповідальності, проте раніше була притягнута два й більше разів до адміністративної відповідальності за ст. 173-2 КУ АП;

3) особа вчиняє насильство два рази, за кожне з них не була притягнута до відповідальності, але була притягнута один раз до адміністративної відповідальності за ст. 173-2 КУпАП.

Звичайно таких комбінацій може бути дуже багато. Проте, коли має місце преюдиційність, важливо встановити новий епізод вчинення насильства після попереднього притягнення до адміністративної відповідальності.

Також потребує окремої уваги питання, як враховувати в разі встановлення систематичності випадки попереднього притягнення особи до відповідальності за злочини, пов'язані з домашнім насильством. Це питання буде детально розглянуто в наступних публікаціях.

\section{Висновки}

Ознака «систематичності» домашнього насильства не така проста, як видається на перший погляд. Для правильного її встановлення необхідна наявність двох критеріїв: кількісного та якісного. Проведене дослідження дає можливість зазначити, що зміст кількісного критерію систематичності як ознаки домашнього насильства ст. 126-1 КК України передбачає вчинення особою три і більше разів діяння, і ця сукупність містить 
також попереднє притягнення до адміністративної відповідальності. Важливо також зауважити, що якщо особа за всі діяння вже була притягнута до адміністративної відповідальності за ст. 173-2 КУпАП, то повторне іï̈ притягнення до кримінальної відповідальності за ст. 126-1 КК України як за вчинення систематичних дій, на нашу думку, буде порушенням принципу «non bis in idem».

\section{Список використаних джерел:}

1. Бажанов М.И. Множественность преступлений в уголовном праве Украины. Харьков : Право, 2000. 128 с.

2. Дудоров О.О., Хавронюк М.I. Відповідальність за домашнє насильство і насильство за ознакою статі (науково-практичний коментар новел Кримінального кодексу України) / за ред. М.I. Хавронюка. Київ : Ваіте, 2019. 288 с.

3. Вирок Буського районного суду Львівської області від 1 березня 2019 p. URL: http:// www.reyestr.court.gov.ua/Review/80203000.

4. Вирок Мукачівського міськрайонного суду Закарпатської області від 28 березня 2019 р.
URL: http://www.reyestr.court.gov.ua/Review/ 80777212 .

5. Вирок Лугинського районного суду Житомирської області від 3 травня 2019 p. URL: http:// www.reyestr.court.gov.ua/Review/81514778

6. Вирок Овруцького районного суду Житомирської області від 8 травня 2019 p. URL: http:// www.reyestr.court.gov.ua/Review/81587757.

7. Домашнє насильство: прояви та відповідальність : роз'яснення Ватутінського міського суду Черкаської області. URL: https:// court.gov.ua/press/general/656541/.

8. Конвенція про захист прав людини i основоположних свобод : прийнята й проголошена Генеральною Асамблеєю ООН 4 листопада 1950 p. URL: http://zakon3.rada.gov.ua/laws/ show/995_004.

9. Case of Oliveira v. Switzerland, Judgment of 30 July 1998, App. no. 25711/94. URL: http:// hudoc.echr.coe.int/eng?i=001-58210.

10. Дроздов O.M. Non bis in idem - європейський орієнтир для забезпечення сталості та єдності судової практики Верховним Судом (за матеріалами практики Європейського суду з прав людини) / Право Украӥни. 2017. № 6. С. 110-132.

The article deals with the notion of "systematic actions" as a feature of domestic violence. It is established that actions considered systematic if they satisfy two criteria: 1) quantitative that is frequency of actions taken and 2) qualitative which means linkage and consistency of actions that form a certain line of conduct of perpetrator towards a specific victim or victims. One may assert that there is a systematic nature only if both criteria are present. The quantitative criterion presupposes that a person commits an act three or more times and this aggregate also includes preliminary prosecution of administrative responsibility. It was concluded that systematic nature of infliction of physical, psychological or economic violence (hereinafter violence) within the context of Article 126-1 of Criminal Code of Ukraine encompasses next cases: a person commits violence three or more times for each of which he wasn't held responsible; a person commits violence for which he wasn't held accountable while was found to be administratively liable for previous two or more acts of violence according to Article 173-2 of the Code of Administrative Offences "Commission of domestic violence, genderbased violence, violation of temporary restraining order or failure to notify on a place of temporary residence”. There could a plethora of possible combinations, however, in case of prejudice it is important to establish a new episode of violence following prior case of accountability for administrative offence. It is concluded that based on the case-law of European Court of Human Rights in case of commission of domestic violence whereas a person in question was found to be administratively liable for the offences under Article 173-2 "Commission of domestic violence, gender-based violence, violation of temporary restraining order or failure to notify on a place of temporary residence" it would be a violation of "non bis in idem" principle laid down in Article 4 of the Protocol No. 4 to the Convention of human rights and fundamental freedoms to prosecute such person for the committed offences under Article 126-1 of Criminal Code of Ukraine.

Key words: domestic violence, systematic nature, systematic nature of domestic violence, non bis in idem. 